\title{
The policies and politics of teachers' initial learning: the complexity of national initial teacher education policies
}

\section{Ian Hardy, Rachel Jakhelln \& Ben Smit}

To cite this article: Ian Hardy, Rachel Jakhelln \& Ben Smit (2020): The policies and politics of teachers' initial learning: the complexity of national initial teacher education policies, Teaching Education, DOI: 10.1080/10476210.2020.1729115

To link to this article: https://doi.org/10.1080/10476210.2020.1729115

曲 Published online: 03 Mar 2020.

Submit your article to this journal $๘$

LII Article views: 101

Q View related articles ¿

View Crossmark data $־$ 


\title{
The policies and politics of teachers' initial learning: the complexity of national initial teacher education policies
}

\author{
lan Hardy (D) ${ }^{a}$, Rachel Jakhelln (D) ${ }^{b}$ and Ben Smit $\mathbb{D D}^{c}$
}

aSchool of Education, The University of Queensland, Brisbane, QLD, Australia; ${ }^{b}$ Department of Education, UiT the Arctic University of Norway, Tromsø, Norway; 'Graduate School of Teaching, Leiden University, Leiden, The Netherlands

\begin{abstract}
This paper analyses the nature and complexity that characterize the broader policy and political conditions of teachers' initial learning within and across three different national settings. Drawing upon the transnational notion of 'fast policy', we show how neoliberal policies and associated policy artefacts constitute specific, national initial teacher education policies in Norway, Australia and the Netherlands. At the same time, we also indicate how hegemonic ideas and ideals mutate as part of these policy mobilities, thereby problematizing performative policy discourses. We do so by identifying and reflecting on how the 'markers' of fast policy are developed and how they are simultaneously challenged by alternative more collective, contextresponsive conceptions of professional learning. In this way, we indicate how even as neoliberal instantiations of fast policy mobility unfold within specific national contexts, more collective, context-relevant approaches to teachers' learning also exist, which can challenge performative policy conditions.
\end{abstract}

\section{ARTICLE HISTORY}

Received 26 November 2018 Accepted 7 February 2020

\section{KEYWORDS}

Fast policy; performativity; neoliberalism; initial teacher education; education policy

\section{Introduction}

This paper analyses the nature and complexity of dominant discourses in initial teacher education (ITE) policies under current political conditions in and across different national contexts. To do so, we draw suggestively upon specific instances of teachers' initial learning in policies and associated politics informing different initial teacher professional programs in Norway, Australia and the Netherlands. The research explores whether and how teachers' learning is influenced negatively by more neoliberal discourses, as well as opportunities to engage with alternative practices and processes in more value-based educational ways (Biesta, 2010). In doing so, we seek to show whether the policy conditions in these contexts also possess within them the discursive capacity and advocacy for alternative approaches and foci within teacher education, particularly those that give greater credence to the specificity of local circumstances, teachers as inquirers, and the more collective nature of teachers' learning.

Ultimately, we argue it is through better understanding the contradictions and potentialities within such policies that we are able to contest performative practices at the local 
level. By focusing upon policy, we give credence to concerns about what has been described as the 'struggle with the primacy of policy' in relation to teacher education (Trippestad, Swennen, \& Werler, 2017). At present, we argue, such an approach is dominated by concerns about how to make teacher education more responsive to narrow conceptions of educational outcomes, including results on international standardized literacy and numeracy tests. (This relates most obviously to PISA, PIRLS and TIMSS, even as these tests assess more than just literacy and numeracy).

\section{Initial teacher education policy reform as a complex and contested global phenomenon}

The focus upon improving teacher quality through teacher education is construed as a global phenomenon (Akiba, 2017). The attention to teacher education can be seen as part of a broader more neoliberal approach to educational reform. Even though the term 'neoliberalism' is heavily critiqued (Rowe, Lubienski, Skourdoumbis, Gerrard, \& Hursh, 2019), by a neoliberal approach, we mean policies and practices actively developed by governments that emphasise market-based practices as an ethic in themselves and that have real-world material effects in practice (Harvey, 2005). Such approaches encourage individualism, and in educational terms, foreground a conception of the individual learner, rather than learning as a collective enterprise (Connell, 2013). This is an approach in which '[i]ndividually targeted expert treatment is presented again and again as the solution to problems, rather than collective action to change the conditions from which the problems arise' (Connell, 2013, p. 108). This more collective action entails cultivating modes of social solidarity and support that place trust in the actions of people working together to enhance social practice - in this case, in relation to initial teacher education provision. The attention to 'chang[ing] the conditions' (Connell, 2013, p. 108) also foregrounds the importance of context as an important part of these collective efforts; such practices are always situated in specific settings and specific relationships in these material settings - which Schatzki (2002) refers to as the 'site of the social'. In contrast, more neoliberal approaches entail implementing a series of management-oriented steps to achieve more individualistic outcomes that purportedly exist beyond context. In this sense, neoliberalism is also a contradictory force; at the same time it seems to foster increased deregulation, it also seeks to control the nature of social, political (and in our case, educational) practices that transpire (Connell, 2013).

Within these broader neoliberal conditions, there is a global policy consensus that teacher education needs to be improved to meet the challenges of the twenty-first century (Darling-Hammond, 2010; Hökkä \& Eteläpelto, 2014; Murray, 2008). Concern about the quality of initial teacher education in multiple countries, concerns about the lack of connection between theory and practice in teacher education, and concerns about students' achievement have all been construed as reasons to improve teacher education in different nation-states (cf. Trippestad et al., 2017). The focus on student achievement particularly in relation to literacy, numeracy and science - has involved considerable attention to results on international large-scale assessments, particularly PISA. These PISA results have then been used to critique teacher education (Trippestad et al., 2017). These international assessments, associated policy reports (including from bodies such as the OECD, UNESCO, World Bank), as well as various media portrayals of teaching and 
teacher education as poor quality, all contribute to the 'global dynamics' and pressure upon national governments to reform teacher education (Akiba, 2017).

As part of this work, various forms of 'policy borrowing' have also occurred. Such 'borrowing' is part of a broader political discourse focused on trying to cultivate 'best practice' in different national contexts. These emphases on 'best practice' have arisen, in part, because of fears about falling behind on international league tables, which are seen as proxy measures for economic development. These politics of externalization reconstitute how national education reform is characterized (Takayama, 2010), with increased emphasis upon various successful systems as 'reference societies' - countries to which other countries need to refer to improve their practice. Consequently, a 'politics of externalization' is at play, and can be understood as the tendency to refer to other national systems deemed as more successful than one's own in order to generate a sense of angst about the need for reform, and as a source of ideas about the sorts of reform that are needed (Schriewer, 2000; Steiner-Khamsi, 2000). This has included the focus upon 'looking east' to learn from certain east Asian educational systems seen as successful, as reflected in PISA results (Sellar \& Lingard, 2013).

Within this broader context of comparison and competition, initial teacher education is construed as something of a 'policy problem' (Cochran-Smith \& Fries, 2008). In this context, issues of 'quality' have been foregrounded in teacher education and linked to economic prerogatives (Cochran-Smith, 2016). The quality of teachers is seen as the 'missing link' in this debate, with teacher education understood as responsible for the initial development of a sufficient number of 'quality teachers' to supply schools. Consequently, 'a new national preoccupation with the quality and supply of teachers is now almost universal' (Furlong, Cochran-Smith, \& Brennan, 2009, p. 1). Also, in the context of a 'shift to neoliberal economics,' where 'individualism, free markets and private good(s) have taken precedence over other goals' (Cochran-Smith, 2016, p. xii), various alternative teacher education models have been deployed to try to enhance the quality of teachers. Such alternatives have been able to exert influence because various 'reform' regimes frame the future as unpredictable. In this context, teacher education is seen as needing to be released from a bureaucratic, 'planning' regime characterized by longer-term coordination that makes it difficult to be responsive to constant change (Trippestad et al., 2017). In such a context, initiatives such as 'Teach for America', and its various international derivatives, with their focus upon taking 'the best' graduates and 'fast-tracking' them to encourage them to become teachers as a way to more rapidly enhance the quality of the teaching workforce (particularly serving disadvantaged communities), have gained traction. The implication is that longer-term teacher education programs are less effectual, and more of a problem than a solution to broader economic needs.

These contradictory efforts to reduce bureaucratisation alongside efforts to increase regulation over standards and outcome (Zeichner, 2014) are expressed differently in different national contexts. In the English context, the 'solution' to the problem of teacher education has included positioning much teacher education in schools to ensure it is more 'relevant' to classroom practice (Gilroy, 2014). This has occurred in conjunction with the development of various 'standards frameworks, which set out explicitly what it is that teachers should be able to do and setting conditions for the provision of teacher education' (Menter, 2016, p. 3). In the USA, Amrein-Beardsley, Lawton, and Ronan (2017) indicate a tightening focus upon standards is expressed in multiple ways, including 
how schools of education have to provide evidence of how their programs are responsible for K-12 student learning of their students, particularly via standardized literacy and numeracy test scores.

However, this is not straightforward, and as Amrein-Beardsley et al. (2017) also show, this push to connect teacher education programs and K-12 test scores has been heavily criticised. Struggle and contestation are also evident in debates between advocates of teacher education that prepare teachers as long-term professionals embarking on a career, including as researchers of their own practice, and short-term technicist approaches focused on improving standardized test scores (Zeichner, 2018). These approaches do not exist in 'pure' form, but teacher education is instead characterized by intersections between these approaches, and other reforms, that are 'stacked like geological layers on top of each other' (Trippestad et al., 2017, p. 5). Teach for All, for example, as an off-shoot of Teach for America, has been taken up differently in different national contexts (Straubhaar \& Friedrich et al., 2015), even as the initiative seeks to homogenize 'solutions' by advocating various forms of data collection, data use, and the universalizing of the language of data as the solution to such concerns (Friedrich, Walter, \& Colmenares, 2015).

While there is a focus upon various forms of standardization of teacher education, as well as a logic of 'data speak' in relation to such standardized, deregulated initiatives, these are not the only influences at play. Solbrekke and Sugrue (2014) refer to how professional accreditation of initial teacher education programmes in Ireland has fostered the development of what they refer to as 'multiple performance scripts', reflecting discourses of both professional responsibility and accountability. In Scotland, there is considerable public and political trust, as teacher education has sought to build strong partnerships between universities and schools, and has become increasingly professionalised (moving towards Masters level provision for all) (Gray \& Weir, 2014); this is an example of a more 'collective' approach to teacher learning, involving, in the Scottish context, an ongoing working partnership amongst key stakeholders: local and national government, the General Teaching Council for Scotland, schools, teacher education institutions, teaching unions, parents and pupils. Finnish teacher education has also been largely research-based for decades, and characterized by conventional ideas and forms, even as the relations between theory and practice 'in practice' are challenging (cf. Hansén, Forsman, Aspfors, \& Bendtsen, 2012; Toom \& Husu, 2012). There is an effort to ensure the 'product' of Finnish teacher education is 'a principled professional who needs moral competence in pedagogical encounters' (Tirri, 2014, p. 600). In Canada, from a more personal perspective, Howe (2014) argues teacher education has helped foster multiculturalism, global citizenship education, enhanced leadership, as well as a comprehensive curriculum, and strong attention to teaching and learning, even as the teacher education landscape is characterized by ongoing and sometimes problematic reform. More productive reform is also evident in the policy landscape in Alberta, where there are no fast-track approaches to becoming a teacher, and where there is a strong focus upon teacher learning and development rather than testing and external accountability (Zeichner, 2018). Consequently, even as the global landscape of teacher education reflects the influence of neoliberal, homogenized and standardized approaches to the provision of teacher education, these are not the only forces at play. That is, there are challenges to how these more homogenized approaches assume that all countries should 
adopt a focus upon the same kinds of data (literacy and numeracy test results) as measures of their success or failure. And there are also challenges to standardized measures of these data - particularly in the form of standardized literacy and numeracy tests. Reliance upon such individual measures of student achievement encourage similarly individualistic approaches to measuring the effectiveness of ITE.

\section{Conceptual resources: 'fast policy' and the particularity of educational practice}

Arguably, more reactive reforms align strongly with what Peck and Theodore (2015) have referred to as 'fast policy'. In what they describe as a 'perpetually accelerating and everconnected world' (p. xv), Peck and Theodore (2015) argue that various policy conceptions that are construed as 'able to work' - as readily implementable regardless of context have developed a form of cogency that make them irresistible to politicians and policymakers in very different national settings. Policy-making is understood in increasingly comparative terms, and various forms of 'best practice' have come to be promoted, often, seemingly, regardless of context. Nevertheless, the specificity of particular locales also means that the way in which these ideas are engaged is always necessarily different, and dependent upon the specific circumstances that play out in these settings. Peck and Theodore (2015) argue that this does not suggest some sort of neoliberal convergence of ideas, 'but it is to make the more subtle point that those policy-making worlds are becoming more intimately and deeply interconnected than ever before' ( $p . x v i)$; such processes are also more rapid and intense than previously. Fast policy refers to particular sets of social practices and arrangements that foster various forms of policy 'take-up', and which promote the engagement with ideas from one place in different locales, even as there are readily apparent tensions that characterize this process:

Fast Policy is concerned with those social practices and infrastructures that enable and sustain policy "mobility," which enable the complex folding of policy lessons derived from one place into reformed and transformed arrangements elsewhere. It is concerned with friction as well as flow. After all, while some aspects of the policymaking process, like the generation of codified institutional designs and models, seem to be built for travel, there is much that cannot be so easily bottled for export, including charismatic leadership, propitious local circumstances, and the presence of supportive partners (Peck \& Theodore, 2015, p. xvii).

Importantly, Peck and Theodore (2015) argue it is through particular kinds of policy mobility and mutation that broader neoliberal ideals become 'localised' as place-specific practices, rather than simply being 'transferred' into new settings. This is akin to forms of 'policy assemblage', which are presented as a corrective to various kinds of rationaltechnical approaches to policy making and governance (Savage, 2019). At the same time, even as they exert influence, neoliberal approaches are recognized as increasingly uneven and variegated (Brenner, Peck, \& Theodore, 2010). While policy-making sites are becoming more porous and transnational diffusion of ideas seems to be increasing, there is recognition these processes are not necessarily leading to a 'convergence' of ideas at sites of political power. That is, policy mutation as well as policy mobilities occur simultaneously (Peck \& Theodore, 2015). It is at some of these points of 'mutation' that more situated, localized practices arise, and where more productive approaches are 
manifest. Given that education is always necessarily grounded in particular sites and locales, and that 'the process of policy change itself is socially, geographically and historically embedded [and] it is not abstracted, idealized, or decontextualized' (Peck \& Theodore, 2015, p. 20), the theorising of educational policy practices is inherently locally situated. If we take this situatedness as important, this has a mediating effect upon the nature and forms of ideas that can actually transpire - including as advocated in policy.

\section{Analytical approach: national policy reform in context}

To better understand the specificity of fast policy effects in initial teacher education - or what we refer to here as the 'markers' of fast policy - and alternative practices, it is important to refer to actual instances of policies and politics as evidence of various policymaking processes. Given the supposed broad-reaching effects of such fast policy effects in developed contexts, it is not only necessary to compare countries that are engaged in more advanced conceptions of teacher education but also those that possess different national heritages that might be assumed to mediate such effects. To this end, we draw upon a comparative analysis of two European countries with a long history of educational reform in initial teacher education, but also with a varying Scandinavian (Norway), and broadly continental heritage (Netherlands). We also compare an Anglo country (Australia) to see whether and how such differences play out in relation to initial teacher professional development policy making in a considerably different context. Such an approach is in keeping with Page's (2015) comparative analysis (of England, France and Germany in relation to professional standards and competences in initial teacher education), where close empirical analysis across national contexts indicated more divergent, pathdependent influences than may have initially been anticipated.

The research draws upon the primary national government websites for schooling in Norway, Australia and the Netherlands, and particularly the principal national policies pertaining to initial teacher education in these countries. ${ }^{1}$ We draw upon both inductive and deductive approaches, involving close analysis of key themes emerging from the (policy) data, but also in light of relevant theorising (Miles \& Huberman, 1994) - in this case in relation to 'fast policy'. In a sense, by drawing upon the specific discourses outlined in broad educational policies, and policy artefacts, in each national context, we are seeking to be true to valuing the 'specific' over the 'general'. We look closely at key, overarching government educational policies to identify the dominant themes/discourses within and across national contexts. Consequently, at the same time as we are working at a broad, national scale, our research is premised on the assumption that there are important discourses operating at the national policy sphere that can only be accessed and understood through close empirical inquiry into the nature of these policy spaces.

\section{Norway}

During the last three decades, Norwegian teacher education for primary and lower secondary schools has undergone a change from practice-based teacher education to a specialized program at Master's level, with a stronger focus on academic skills and indepth knowledge. This is particularly the case since the most recent reforms in 2017 
(Trippestad et al., 2017). During the same period, the higher education system has undergone a large number of mergers and today thirteen institutions are offering teacher education for primary and secondary school teachers, compared with approximately thirty in earlier times.

The emphasis upon a 5-year qualification for teaching, and the focus on making teaching a graduate course at Master's level, is also explicitly associated with both enhanced status and quality. It is argued that such enhanced provision 'will raise the quality of teacher training, and mean that newly qualified teachers are better prepared for their jobs.' (Norwegian Government, 2016). This reflects globalized concerns about teacher quality, reflecting both more 'professionalizing' discourses, as well as narrower concerns about status. At least in part, there seems to be something of an effort to 'reclaim' accountability in this instance, with a focus upon long-term, substantive teacher education approaches (cf. Cochran-Smith et al., 2018). The webpage from the Norwegian Government on Education foregrounds 'promotion of the status and quality of teachers' (Norwegian Government, 2017). The reform can be seen as a 'governmental measure that is intended to improve quality of teacher education and school efficiency' (Werler, 2017, p. 134). Discursively, this is significant, because it foregrounds the position of the teacher, rather than the practice of teaching. At the same time as a more progressive discourse is evident, and an emphasis upon universities and schools working more closely together, there is an 'individualizing' implication at play, perhaps in keeping with neoliberal approaches (Cochran-Smith, 2016). Furthermore, the emphasis is upon very broad concepts, which are difficult to pinpoint in relation to actual practices. There is an assumption that by somehow addressing concerns about 'status', problematic issues within the profession will also be addressed.

At the same time, there is advocacy for education for increased social cohesion and development. There is an emphasis upon promoting a 'good start in life', 'social levelling' as well as preparing students for the workforce as a means of securing Norway's prosperity (Norwegian Government, 2016). However, reflecting narrower foci upon literacy and numeracy (Zeichner, 2018), there is also an assumption that by linking these broader aims with improved outcomes in literacy and numeracy, these gains can somehow be achieved. While there is support for each child to have the 'best possible preparation for the future', there is also an assumption that deficits in student literacy and numeracy are the principal causes of the lack of this broader social cohesion and economic development:

They [teachers] should give both society and each individual child the best possible preparation for the future. Although Norwegian schools have many strengths, there are still too many students who never achieve good literacy and numeracy skills. The government's new programme [in initial teacher education] will play an important part in tackling this problem. (Norwegian Government, 2017)

The Master's education program is also seen as a developmental tool in this process. The government's Teacher Education 2025: National strategy for quality and cooperation in Teacher Education (Norwegian Government, 2017) foregrounds the need for teachers to develop research-based skills as part of their work, and to engage in collaborative learning with their colleagues: 
(ITE shall) educate professional practitioners. Teachers need to acquire solid, research-based skills and to have access to continued professional development within a professional learning community in order to make informed decisions in their day-to-day work in kindergartens and schools.

However, although a research and development $(R \& D)^{2}$ focus is emphasised in Norwegian teacher education since 2010, it varies greatly in both context and content (Munthe \& Rogne, 2015). The new expectations signal a lack of research-based competence amongst teachers (Trippestad et al., 2017). Nevertheless, the development of research-oriented institutions for teacher educators, such as the Norwegian Post-Graduate School of Teacher Education (NAFOL) and the National Graduate School in Educational Research (NATED) can be understood as recognition of the need to support and strengthen the research-based perspectives of teachers, even as this is challenging work.

The increased focus upon partnership between schools and universities is also an important part of the policy context in Norway and evidence of a more collaborative alternative to more individualistic, neoliberal approaches to teachers learning. The government is advocating stronger relationships in teacher education between schools and universities through the practicum experience, and as a means of fostering researchbased professional development:

The government will put into effect a national framework for partnerships between teacher education institutions and kindergarten/schools for creating teacher education kindergartens and teacher education schools in order to boost the quality of practice training and R\&D-based professional development. (Norwegian Government, 2017, p. 15)

This is a two-fold process, in which both schools and universities are heavily involved in teacher education. Such a response differs considerably from the reductive school-based approaches to teacher learning in England (Gilroy, 2014), even as it does reflect a propensity towards increasing influence of government in decision-making about how best to orchestrate initial professional learning and the accountability agenda therein (Cochran-Smith et al., 2018).

The Norwegian Government has established the Norwegian Agency for Quality Assurance in Education (NOKUT) ${ }^{3}$ to follow the new ITE reform. NOKUT has in turn brought together an international expert group of teacher educators to enhance ITE provision. Reflective of comparative logics (Takayama, 2010), such an approach also reflects a focus on learning from other national settings; in the case of Norway, there is particular reference to Finland. Reflecting a belief in the importance of looking internationally to more 'successful' nation-states (Takayama, 2010), there is a sense in which, in Norway, policy is 'steered' by politicians, even though there are promising possibilities embedded within its policy agenda.

At the same time, there is a sense of urgency about such reforms (cf. Hansén, Sjöberg, \& Eilertsen, 2014). As in other contexts, and reflecting the global policy consensus that teacher education needs to be improved (Darling-Hammond, 2010; Hökkä \& Eteläpelto, 2014; Murray, 2008), this focus upon particular kinds of high status knowledge - associated with literacy and numeracy, and particular forms of research and development also has the potential to marginalise other forms of knowledge. This includes other forms of local and collective conceptions of worth and value, and ways of being and living that have cogency beyond economic parameters. 


\section{Australia}

In Australia, and perhaps more overtly than in the Norwegian context, teacher education has also become a 'policy problem', requiring a myriad of solutions (Mayer, 2014). Recent standards reforms have built directly on the development of earlier national standards for teachers and associated reforms formalised under the previous Labor government (2007-2013). These standards, begun under the Ministerial Council for Education, Early Childhood Development and Youth Affairs (MCEECDYA) in 2009, were endorsed by the federal government in 2010 and released in 2011. These standards have underpinned more recent changes in ITE. At the national level, this has included the Students First policy ensemble - the principal federal government policy for schooling in Australia in 2015/16. As its name suggests, this cluster of policies sought to foreground the nature and place of student learning. These policies have since been updated to emphasise particular discourses around 'quality' teacher education practices. In May 2016, the government released its Quality Schools, Quality Outcomes plan, which focused on:

- Boosting literacy, numeracy and STEM performance;

- Teaching and school leadership;

- Preparing our students for a globalized world;

- Focusing on what matters most and those who need it most;

- Accountability through transparency (Australian Government, 2016).

Arguably, in the Australian setting, the broader policy milieu pertaining to schooling privileges a generic conception of initial and continuing teacher education/learning, and reflects broader policy and political concerns about Australia's relative standing on various international league tables, particularly PISA. This includes the need to 'look east' to learn from countries seen as more successful in PISA at the time (Sellar \& Lingard, 2013). Under the rubric of 'teacher quality', there was an explicit focus upon the 'professionalism' and 'quality' and 'status' of the teaching profession: 'The first step to achieving a quality education, which is so critical for the future of young Australians and our nation, is to lift the quality, professionalization and status of the teaching profession.' (Australian Government, 2018). This was to be achieved through five initiatives: 1) Literacy and numeracy test for initial teacher education students; 2) Agriculture in Education programme ${ }^{4}$; 3) Flexible literacy for remote primary schools programme; 4) Teach for Australia programme, and; 5) The Teacher Education Ministerial Advisory Group (TEMAG). These initiatives have resonance for both initial and continuing teacher education practices, with the first, fourth and fifth of these initiatives explicitly related to initial teacher education.

In relation to initial teacher education, the Literacy and Numeracy Test for Initial Teacher Education Students is a clear example of a reductive approach to teachers' learning, and the increasing influence of standardized literacy and numeracy testing more generally (Zeichner, 2018). Because Australian students had experienced a relative decline in literacy and numeracy in national and international standardized tests, the implication was that their teachers were insufficiently literate and numerate, and a teacher education version of such tests would help rectify this situation. From 1 July 2016, all state Education Ministers agreed to implement the test to ensure all initial teacher education students 
were 'in the top 30 per cent of the adult population for personal literacy and numeracy' (Australian Government, 2018).

Furthermore, the Teach for Australia Program, with its focus upon fast-tracking eligible candidates, was reconfirmed in the 2016 Mid-Year Economic and Fiscal Outlook (MYEFO), with the federal government contributing an additional \$AUD20.5 million (\$USD15 million) for $2016 / 17$ to $2020 / 21 .^{5}$ This is on top of support to date, resulting in a total allocated investment of \$AUD77 million ${ }^{6}$ (\$USD56 million). Ignoring the homogenizing effects of the universalizing of the language of data as the solution to concerns about literacy and numeracy associated with the Teach for All movement (Friedrich et al., 2015), this initiative was construed as a vehicle for addressing concerns about how to attract 'quality' teachers to disadvantaged schooling settings, and into the profession more generally:

The Teach for Australia program aims to fast-track high-calibre non-teaching graduates into disadvantaged secondary schools by providing an employment-based pathway into teaching.

The Teach for Australia program plays an important role in attracting high-quality candidates to the teaching profession who might not otherwise have considered a career in education. (Australian Government, 2018)

The work of TEMAG, appointed by the federal Minister for Education at the time, also reflects global processes of the need to reform teacher education (Akiba, 2017) - specifically 'to provide strong, implementable options to initiate genuine national reform' (Teacher Education Ministerial Advisory Group [TEMAG], 2014, p. viii). This was also associated with raising the quality and status of the teaching profession and was seen as tied to ensuring student teachers were 'ready' for the classroom as quickly as possible. The very title of the report emerging from TEMAG, Action Now: Classroom Ready Teachers, reflects the sense of urgency, immediacy and belief that 'classroom-ready' teachers could be formed through initial teacher education programs, but also the implication that this had not been achieved to date. Also reflecting the influence of processes of examining what is occurring in more 'successful' nation-states (Takayama, 2010), including the push to 'look east' in the context of success in PISA in east Asia (Sellar \& Lingard, 2013), this need for reform was also reflected in explicit reference to the need to enhance student outcomes, and stimulated by concern about declining PISA results since 2000 (TEMAG, 2014).

While not as centralized around schools as in England (Menter, 2016), there was also evidence of recognition of the need for close collaboration between all participants in the work of ITE, particularly schools and universities, as outlined in the introductory letter:

We have concluded that the single most important action to be pursued is the integrated delivery of initial teacher education. This can be achieved through close partnerships between providers, school systems and schools, and underpins improvement to all aspects of the preparation of teachers. (TEMAG, 2014, p. v)

The 'key findings' of the report proper also constituted ITE as largely problematic, requiring considerable oversight and reform, and more standardized practices, and not cultivating confidence in the public more broadly. There was also apprehension about ITE programs not adequately addressing concerns about content knowledge, skills, and the ability of neophyte teachers to be responsive to varying student learning needs: 
Evidence of poor practice in a number of programs - Not all initial teacher education programs are equipping graduates with the content knowledge, evidence-based teaching strategies and skills they need to respond to different student learning needs. (TEMAG, 2014, p. vii)

Reflecting the contested discourses that characterize initial teacher education more broadly, these foci on content knowledge, strategies and skills indicate a traditional, reductive conception of what constitutes ITE, even as the need to be responsive to varying student learning needs was evident.

The government's response to the TEMAG recommendations also indicated a discourse of increased surveillance and scrutiny of ITE in Australia. A 'fact sheet' summarising the government's response included a list of 5 points which strongly reflected TEMAG recommendations and findings, including the need for 'robust assessment of graduates to ensure classroom readiness' (Australian Government, 2015, p. 5). Reflecting concerns about literacy and numeracy in national (NAPLAN) and international test results (PISA, TIMSS, PIRLS), these assessments were to emphasise pre-service students' literacy and numeracy capacities.

Such a response reflects a culture of accountability and centralisation in relation to ITE (Menter, 2016), but of a less 'democratic' variety (cf. Cochran-Smith et al., 2018). Through comparison with other nations' practices (Takayama, 2010), there was also explicit advocacy for 'best practice examples' in relation to practical experience within ITE programs, as well as partnerships between universities, schools and education authorities. The focus upon evidencing 'classroom readiness' was also explicit, again with an emphasis upon 'knowledge and skills' (Australian Government, 2015, p. 8). This work was also to be 'based on the Graduate level of the Australian Professional Standards for Teachers, and focused on school student learning' (Australian Government, 2015, p. 8). Again, these standards were to form the basis for subsequent work. ${ }^{7}$

\section{The Netherlands}

In the Dutch context, reflecting efforts to develop an expansive (beyond economic concerns) and coherent approach to the connection between education and society, three policy domains are combined into one ministry: education, cultural affairs and science ('Ministerie van Onderwijs, Cultuur en Wetenschap $(\mathrm{OCW})$ '). The central aim, the Ministry claims:

Is working on a smart, skilled and creative Netherlands. OCW wants everyone to follow good education and to prepare themselves for independence and responsibility. Furthermore, the Ministry wants everyone to experience culture, and teachers, artists and scientists to be able to do their jobs. (Dutch Government, 2018a; transl. authors)

In Dutch educational policy, stimulated by growing shortages of teachers, and particularly anxiety about falling performance scores of students (cf. Zeichner, 2018), there is concern about both the status and quality of teachers. This is seen as able to be addressed through financial incentives, such as programs to raise the salary of teachers, bursaries for teachers, and revised salary scales based on differentiation through the development of a teacher register ('Lerarenregister') which became active in 2017 (Dutch Government, 2017a). ${ }^{8}$ There are also expectations that professional development will be ongoing, and that teachers will continually work on their practice. 
Interestingly, and reflecting broader concerns about teacher education as a global policy concern (Darling-Hammond, 2010; Hökkä \& Eteläpelto, 2014; Murray, 2008), the government 'wants the professional quality of teachers to be visible and to improve' (Dutch Government, 2018c; transl. authors); this was also based on the 2011 policy Action Plan Teacher 2020, that led to the national program The Teacher Agenda 2013-2020 (Dutch Government, 2013). Significantly, the program was informed by, and developed in collaboration with, and agreed upon by, a wide range of teachers and educational professionals.

Such visibility of teacher quality could be construed in multiple ways. The register could be seen as a vehicle to acknowledge the work and quality of teachers and teacher educators. Bursaries provided by the government as part of this initiative can be understood as a way of valuing teachers, and recognising their potential for improving their own work and learning. However, and at the same time, the register is, in some ways, very bureaucratic - a way of 'keeping track' and 'accounting for' teachers (cf. Menter, 2016).

At the same time, the emphasis upon literacy and numeracy has been used as part of these discourses of 'quality'. Such foci are part of an increased emphasis upon neoliberal economics more broadly, and where issues of 'quality' amongst teachers/pre-service teachers have been foregrounded and linked to these economic prerogatives (CochranSmith, 2016). The result has been explicit advocacy for enhanced literacy and numeracy in relation to both students and teachers:

Good mathematics skills are important for performance at school, on the job market and in society. To further improve mathematical education, the government, education, pupils and parents have made agreements. These agreements are included in the agenda arithmetic education in secondary education and secondary vocational education: de Rekenagenda [the Arithmetic/Mathematics Agenda]. The aim is to continue to improve mathematical education, even though, currently, the arithmetic test does not count for obtaining the diploma in VMBO, HAVO and MBO. ${ }^{9}$ (Dutch Government, 2016; transl. authors)

As in the Australian context, Teacher Education students are required to complete tests and examinations for language and mathematics proficiency at particular levels. For prospective senior secondary teachers, it is necessary to pass such exams at higher, specified levels than for other teachers, but this is implied in graduating; however, in coming years, these expectations will increase as well in all pre-service programs. In addition, as standard procedure, language and mathematics entry tests have been introduced for primary teacher education programs, and these prospective teachers need to pass these tests before they are allowed to commence their studies in teacher education. ${ }^{10}$ Again, this is evidence of the 'problematisation' of teacher education more broadly, and the application of a narrow set of 'policy solutions' to effect desired changes (Cochran-Smith, 2016). This is construed as a way to 'raise' the quality of teachers and teaching, but it is also indicative of a reductive conception of what constitutes a 'good' teacher, and for assessing the quality of education provision. Such an approach reflects broader global discourses in relation to the need to enhance provision of teacher education (Darling-Hammond, 2010; Hökkä \& Eteläpelto, 2014; Murray, 2008) but in more reductive ways. Furthermore, reflecting a broader politics of looking externally to what is occurring in other nations to substantiate the need for reform (Takayama, 2010), and emphasis upon particular reference societies in relation to PISA (Sellar \& Lingard, 2013), this emphasis upon testing is also an explicit response to Dutch PISA scores in literacy and numeracy. 
Reflecting conservative approaches to policymaking, the conception of research that is promoted in the Dutch case is also more 'traditional', involving teachers taking up research knowledge developed by others, and often associated with randomizedcontrol approaches. One heavily state-subsidized policy initiative of note, 'Educational evidence' [OnderwijsBewijs], has involved investing 22.5 million Euros (\$USD25.5 million) in 37 research projects aimed at finding research evidence in support of specific educational approaches/intervention programs that 'work'. Such an initiative is construed as a vehicle for providing teachers with 'evidence-based' information to 'apply' to their teaching. One of the ways the Ministry disseminated the results of the projects were through a special insert in an issue of Didactief, a Dutch professional teaching journal. The special issue, 'Opinion and research for school practice' (OnderwijsBewijs, 2014), summarises the nature of these 37 projects, and is positioned as a summation of 'what works':

It is not enough to have 'fun' in education; it should be based on 'what works'. It stimulates development of evidence-based education innovation (2014, p. 4, transl. authors).

In keeping with traditional conceptions of research emphasising the value of randomized control approaches (Slavin, 2002), this program reflects the focus upon evidence-based research of a particular ilk, and seeks to find ready and rapid 'solutions' to challenging problems that could be applied across all schooling contexts. The publication concludes: 'Good intentions are not enough for students. They deserve innovations that make going to school more interesting and educational' (p. 16; transl. authors). Here, the 'good intentions' referred to are those of teachers, and the implication is that teachers, while perhaps caring for and about their students, do them a disservice if they do not adopt the approaches outlined in such an overview of 'best' practice.

However, and at the same time, that research should be undertaken by teachers is significant in this policy framing. The role of the teacher should include work as a teacherresearcher. This involves developing a research attitude/inquiry stance. Such a stance entails various types of research-related teacher activities including a) looking critically at one's own practice; b) applying results from educational research to one's own practice, and; c) undertaking educational research as a practitioner-researcher (Zwart, Smit, \& Admiraal, 2015). If we engage with action research substantively, this entails critiquing policy and practice.

However, this takes time, and begs the question of how much 'critical' work is possible in this broader context? How much 'teacher agency' can be exercised? This involves providing the professional 'space' to allow teachers to develop and decide how they will teach. The departmental maxim 'The teacher in charge again' reflects this policy stance; this has been phrased by the Minister as: 'the teacher's interests must be paramount. And then the teacher can be best at the helm as well.' (Dutch Government, 2018b, section 'Regie terug bij de leraar'). Such advocacy seems like teachers have more influence and control over the circumstances of their work and learning, but in a broader global policy context that exerts influence at the national level, albeit differently in different contexts (Akiba, 2017), the extent to which teachers do have control over their circumstances is an open question. In a context of increased and often reductive accountability (Menter, 2016) rather than 'democratic' accountability (Cochran-Smith et al., 2018), pressure to address teacher shortages, concerns about 'low' quality, and the need to learn from the lessons of the 37 projects, all suggest a sense of urgency, and pressures of time. 
However, practice is also recognized as site-specific, and teachers need to be involved, and work as active agents in developing their own practice. As in other national settings, this represents a significant tension in the Dutch case.

\section{Discussion: the 'markers' of fast policy in initial teacher education in Norway, Australia, and the Netherlands}

The table below (Table 1) provides a summary of nature, complexity and contestation of initial teacher education reforms as expressed in key national policies within and across the three national contexts. These cross-national discourses include what we describe as some of the contested 'markers' of 'fast policy' effects in Initial Teacher Education. These 'markers' provide evidence of the effects of neoliberal iterations of educational practice, but they also indicate contrary and contrasting approaches, and thereby gesture towards 'points of possibility' for the cultivation of enhanced practices in initial teacher education. Importantly, these 'markers' are not simply left to chance but embedded within the specific national policy reforms in each context, sometimes in significantly 'mutated' forms in relation to broader neoliberal principles and practices, but sometimes more overtly as instances of more neoliberal policy mobilities (Peck \& Theodore, 2015).

The commonality of the discourses across the national contexts indicates something of the 'global policy consensus' about the need for improvement in teacher education (Darling-Hammond, 2010; Hökkä \& Eteläpelto, 2014; Murray, 2008). However, this is also expressed in varied and complex ways. The focus on 'quality' of teachers reflects broader global processes even as these have been taken up differently across national contexts (Akiba, 2017). While a more education-oriented approach is evident in how teacher proficiency in Norway is construed as enhanced through an extended period of preparation through a Master-level program, in the Netherlands, 'quality' of teachers is seen as enhanced through salary, and particularly through the more differentiated register of teachers. However, again, while this register is also construed as a way to raise visibility of teachers, whether and how this is for more accountability versus recognition purposes is open to question. While teacher education is something of a 'policy problem' (CochranSmith \& Fries, 2008), the individualism enabled through such a register may also feed into neoliberal logics that have come to characterize ITE recently (Cochran-Smith, 2016); the register serves as a mutation of neoliberal ideals (Peck \& Theodore, 2015). In Australia, more 'mobility' than 'mutation' is perhaps evident in how concerns about 'quality' are to be addressed by 'parachuting' in high-performing students from other backgrounds through the Teach for Australia initiative, even though the evidence of the effectiveness of such programs is very much contested (Straubhaar \& Friedrich et al., 2015).

Reflecting global pressures for reform in ITE more broadly (Darling-Hammond, 2010; Hökkä \& Eteläpelto, 2014; Murray, 2008), there is also a sense of urgency surrounding ITE. This is sometimes expressed very explicitly, as is the case in Norway, even as the reforms in place seem to be grounded in a longer-term approach (e.g. via Masters' projects). In the Netherlands, ITE is undertaken within a broader context in which there is a focus upon 'educational evidence' of 'what works', and it is the results from the 37 specific projects foregrounding particular educational issues which are of much interest, and that inform this sense of urgency for reform. In Australia, the marker of no-time-to-waste is evident in the very title of the TEMAG Report - Action Now: Classroom Ready Teachers - and its 
Table 1. Key policy discourses within and across national contexts (as evident in national websites).

\begin{tabular}{|c|c|c|c|}
\hline Key policy discourses & Norway & Australia & Netherlands \\
\hline Status of teachers & $\begin{array}{l}\text { Concern about 'status' of } \\
\text { teachers; Master level } \\
\text { qualification; focus on } \\
\text { learning outcomes, } \\
\text { knowledge - skills - } \\
\text { competence. }\end{array}$ & $\begin{array}{l}\text { Status to be enhanced } \\
\text { through literacy and } \\
\text { numeracy test for } \\
\text { prospective teachers, } \\
\text { Teach for Australia, TEMAG. }\end{array}$ & $\begin{array}{l}\text { Financial incentives to raise } \\
\text { the salary of teachers, } \\
\text { bursaries for teachers, } \\
\text { revised wage scales. }\end{array}$ \\
\hline Quality of teachers & $\begin{array}{l}\text { Emphasis upon a 5-year } \\
\text { qualification for teaching } \\
\text { and the focus on making } \\
\text { teaching a graduate } \\
\text { course; quality in teacher } \\
\text { training - school efficiency. }\end{array}$ & $\begin{array}{l}\text { Teach for Australia construed } \\
\text { as a vehicle to improve } \\
\text { teacher quality; need for } \\
\text { content knowledge, } \\
\text { evidence-based teaching } \\
\text { strategies and skills; need } \\
\text { for stronger 'quality } \\
\text { assurance' of ITE programs. }\end{array}$ & $\begin{array}{l}\text { Focus on 'quality' of teachers; } \\
\text { seen as enhanced through } \\
\text { salary, teacher bursaries, } \\
\text { and a teacher register; } \\
\text { register also way to raise } \\
\text { visibility of teachers } \\
\text { (accountability vs } \\
\text { recognition). }\end{array}$ \\
\hline $\begin{array}{l}\text { The role of literacy and } \\
\text { numeracy } \\
\text { (including literacy } \\
\text { and numeracy } \\
\text { testing) }\end{array}$ & $\begin{array}{l}\text { Concerns about deficits in } \\
\text { literacy and numeracy but } \\
\text { also concerns about } \\
\text { threats to social cohesion } \\
\text { and economic } \\
\text { development }\end{array}$ & $\begin{array}{l}\text { Aim for all initial teacher } \\
\text { education students 'being } \\
\text { in the top } 30 \text { per cent of } \\
\text { the adult population for } \\
\text { personal literacy and } \\
\text { numeracy'; literacy and } \\
\text { numeracy test to be } \\
\text { completed by students } \\
\text { before they can graduate } \\
\text { from ITE programs } \\
\text { (concerns about PISA } \\
\text { results). }\end{array}$ & $\begin{array}{l}\text { Math and language tests for } \\
\text { ITE students in primary } \\
\text { education; must be } \\
\text { satisfactory result to } \\
\text { continue in ITE; increase in } \\
\text { expectations of teachers' } \\
\text { competencies in these } \\
\text { domains in coming years. }\end{array}$ \\
\hline $\begin{array}{l}\text { Conception of } \\
\text { research (including } \\
\text { action research) }\end{array}$ & $\begin{array}{l}\text { Teachers are expected to } \\
\text { analyse their own } \\
\text { teaching, based on } \\
\text { research, and through this } \\
\text { analysis, be able to change } \\
\text { their teaching; Master's } \\
\text { projects to serve as vehicle } \\
\text { to bolster practice-based } \\
\text { teacher capacity. }\end{array}$ & $\begin{array}{l}\text { Advocacy for 'best practice } \\
\text { examples' (research as } \\
\text { something external to } \\
\text { teachers' work, but which } \\
\text { they should incorporate } \\
\text { into their practice); also, } \\
\text { partnerships between } \\
\text { universities, schools and } \\
\text { education authorities; } \\
\text { a narrower focus upon } \\
\text { 'classroom readiness', with } \\
\text { an emphasis on } \\
\text { 'knowledge and skills.' }\end{array}$ & $\begin{array}{l}\text { 'Traditional' approach to } \\
\text { research (randomized- } \\
\text { control, generalized } \\
\text { knowledge); however, also } \\
\text { support for research } \\
\text { undertaken by teachers } \\
\text { (teacher-researcher). }\end{array}$ \\
\hline $\begin{array}{l}\text { Time and Timeliness } \\
\text { (sense of urgency, } \\
\text { or otherwise) and } \\
\text { impact upon } \\
\text { professional agency }\end{array}$ & $\begin{array}{l}\text { A sense of urgency for reform; } \\
\text { a stronger focus on } \\
\text { efficiency and technical } \\
\text { aspects of teaching and } \\
\text { learning, but also longer- } \\
\text { term professional learning }\end{array}$ & $\begin{array}{l}\text { TEMAG Report Action Now: } \\
\text { Classroom Ready Teachers - } \\
\text { recommendations as } \\
\text { 'practical, based in } \\
\text { evidence and calculated to } \\
\text { succeed' ITE; NAPLAN and } \\
\text { PISA as creating sense of } \\
\text { urgency vis-à-vis results in } \\
\text { Australia; continuing } \\
\text { concerns around status. }\end{array}$ & $\begin{array}{l}\text { Growing teacher shortages; } \\
\text { urge for instant measures } \\
\text { to achieve quality goals; } \\
\text { focus upon 'educational } \\
\text { evidence' of 'what works' } \\
\text { indicating a sense of } \\
\text { urgency (from } 37 \text { projects } \\
\text { focused on specific } \\
\text { educational issues); this } \\
\text { reduces teacher agency. }\end{array}$ \\
\hline
\end{tabular}

recommendations and advocacy for ITE as 'practical, based in evidence and calculated to succeed'. Such articulations of urgency show how neoliberal processes have not simply been institutionally mediated in local sites, but actively and institutionally embedded (Peck \& Theodore, 2015).

Under such circumstances of urgency, the indicators that attract considerable attention are those considered most reflective of the current state of educational attainment. The 
result is an emphasis upon literacy and numeracy in relation to ITE, which is perhaps reflective of the homogenizing effects of global discourses around the need for enhanced student outcomes. Students' achievement forms part of the reasoning behind the global quest for better solutions and continual improvement of teacher education (cf. Trippestad et al., 2017). In Norway, deficits in literacy and numeracy are construed as a threat to social cohesion and economic development. In the Netherlands, the introduction of an arithmetic test for ITE students and the requirement that students must achieve satisfactory results to enter ITE reflects the focus upon standardized forms of data, and the universalising of discourses of data as the solution to the educational problem (Friedrich et al., 2015). In Australia, this focus upon specific reified measures of literacy and numeracy is perhaps most overt, with ITE students needing to sit a literacy and numeracy test before they can graduate from ITE programs. Green, Reid, and Brennan (2017) refer to how the work of teacher education has become increasingly abstracted in Australia, at the same time as it is being recalibrated to serve instrumental purposes. Under these circumstances, Green et al. (2017) argue, the very soul of the teacher educator is in play and struggled over (cf. Zeichner, 2018). However, again, these forces are expressed differently and less overtly in Norway and the Netherlands, even as their effects are significant in these contexts as well.

Similarly, close analysis of ITE policies in each country shows common concerns about the status of teachers, but also how these are operationalised differently in each context. The Teach for Australia in the Australian context adopts a 'faster' policy approach, as evident in the standardized forms of data considered most beneficial to 'measure' the 'effectiveness' of the program (cf. Friedrich et al., 2015). At the same time, increased marks in English and mathematics to enter ITE programs, greater emphasis upon literacy and numeracy in schools, and more credits in mathematics and English are all construed as productive in the Netherlands. Such initiatives seek to foster professionalism and enhanced 'status' of teachers and teacher educators; they can be understood, in part, to be trying to cultivate more education-oriented approaches and foci. However, at the same time, they potentially serve as vehicles to limit and control the nature of the learning that occurs within ITE (Menter, 2016). By contrast, while more 'fast policy' approaches characterise the emphasis upon salary and wage scales in the Dutch context, there appears to be a longer-term, 'slower' policy approach adopted in Norway. This is evident in the more considered focus upon enhancing status through a more thorough 5-year Master-level program in Norway, not just salary. This Norwegian approach to fostering teacher inquiry more substantively over time is indicative of a more genuine educationally oriented approach to ITE.

Conceptions of research also indicate faith in conservative logics associated with neoliberal approaches, as well as challenges to these approaches, and variegated expressions of these phenomena in the different national contexts. In Norway, the new Master's project seems to serve as a vehicle to ensure teacher capacity, involving a longer-term more research-informed as well as research-informing approach; again, this reflects a more educative approach to ITE. By contrast, the approach to research in ITE in the Netherlands seems more conservative. A 'traditional' approach to research (randomizedcontrol) is evident; however, there is also support for research undertaken by teachers (as teacher-researchers) through looking critically at one's own practice, applying results from educational research to one's own practice, and undertaking educational research 
as a practitioner-researcher. In Norway, it seems action research or similar practices are something of a 'standard' way of undertaking teacher education, but this is not quite so apparent in the Dutch context. Such an approach seems most marginalised in the Australian context. Perhaps this reflects an orientation to research that is not aimed at substantively enhancing educational opportunities in schooling contexts, but simply 'improving on' practices already established and embedded in schooling settings, and aligning educational outcomes with more economic indicators of growth and development. In the Australian context, the emphasis upon 'classroom readiness' is reflective of a more conservative, controlling approach to teacher education (Menter, 2016). Such an approach seems focused on providing the conditions to ensure enhanced outcomes (as measured by standardized literacy and numeracy tests in particular) as quickly as possible.

In a sense, we can talk about a sort of 'doubleness' in relation to these 'markers' of fast policy in each nation, as well as significant differences across contexts. Some practices seem more neoliberal, while others appear more genuinely education-oriented, but these are expressed variously in different settings. There is a valuing of teacher reflection and research, and through the development of Master's programs in ITE in Norway, for example, there is a sort of academic nation-building. Knowledge is important, helping constitute human capital, but also potentially helping to forge enhanced understandings of practice as situated. This seems like the opposite of neoliberal conceptions of ITE with their focus upon individualism and economism alone (Cochran-Smith, 2016).

However, the pedagogical authority of teacher educators and teachers is also under pressure in all these contexts - perhaps more so in Australia than the Netherlands, and more so in the Netherlands than Norway. While teacher education is more than just applying techniques - involving on-the-spot decision-making and addressing needs of individual students which cannot be prescribed by 'what works' approaches (Trippestad et al., 2017) - there is clearly evidence of more control (Menter, 2016) even as this has been heavily contested (Amrein-Beardsley et al., 2017). While the teacher as researcher may be advocated as able to engage in inquiry in some settings more so than others, emphases upon quickly improving literacy and numeracy results, and explicit attention to these areas in ITE, reflect the influence of reductive policy mobilities, which are seen as necessary to redress shortcomings in teacher education. The governments in all three settings have not acted in isolation, even though some, such as Norway, seem to have been more successful at 'setting the agenda' through various advisory panels informing the nature of the teacher education that should occur. Broader, global influences have exerted influence, leading to a sense of steering - a version of 'steering from a distance' (Kickert, 1995) - even if this operates very differently in different contexts; through comparative logics (Takayama, 2010) and emphases upon PISA, the OECD is revealed as a key player in this process (Werler, 2017).

Such a position is contrary to 'situated' and more collaborative approaches to teachers' work and learning, even as these more education-oriented approaches simultaneously exist in these and other settings (Howe, 2014; Tirri, 2014; Zeichner, 2018). Our research indicates how various policy mobilities in relation to more neoliberal approaches and foci have been expressed variously, in sometimes mutated forms, such that more overtly economistic and individualistic approaches have not been adopted wholesale or in some sort of pure fashion. Importantly, while narrower foci upon literacy, numeracy, status, teacher quality and research are evident, 'this does not 
beckon a flat earth of standardized outcomes or some socioinstitutional monoculture' (Peck \& Theodore, 2015, p. 18). More long-term, collaborative, inquiry-based educationoriented approaches are still evident.

\section{Conclusion}

Of course, transnational policy sharing can be positive for enabling the sharing of insights from different contexts to foster understanding within other traditions/cultures/contexts. In the research presented here, this includes learning how research-informed ITE approaches are construed in Norway, and how these might inform ITE policymaking in the Netherlands, and especially Australia. Identifying commonalities across contexts can also serve, however, to highlight how particular perspectives and approaches have exerted influence in potentially reductive ways. While various 'fast policy' phenomena are certainly not expressed homogenously, seeking to show the variegated 'markers' of such fast policy in all their hybridity in relation to initial teacher education is a way of flagging potentially problematic policy conditions in particular national contexts. It also signals a way to potentially avoid 'learning' from those settings in which issues of context are not adequately foregrounded or addressed. In this article, we have sought to show not only how various policy mobilities and mutations occur in relation to initial teacher education but also how they may become embedded in national policy discourses. The varied national contexts show how such policy mobilities can be expressed in a multitude of ways in and across such settings.

Interestingly, those teacher education programs that are most successful in influencing practice are those that are a part of broader systems - that take a systemic approach to education more broadly (Darling-Hammond, 2017). Darling-Hammond et al. (2017) identify such 'systemness' as involving recruitment of candidates, teacher performance assessments, collaborative learning amongst teachers, leadership - through all phases of the career - as part of 'quality' systems. In a way, fast policy approaches enable a focus on some of these elements of successful systems but downplay others. Rather than engaging with reductive 'fast policy' foci and effects, we support what Zeichner (2018) refers to as 'Teacher Education 3.0.' These contrast with traditional, current teacher education programs in universities ('1.0 programs') or those supported by reformers who seek to displace such programs with entrepreneurial and market-based and competitive initiatives ('2.0 programs'), whether they be run by districts, non-profit or for-profit bodies. Instead '3.0 programs' are 'a new, more community- and school-centred model for programs in which colleges and universities, districts, teacher unions, and local communities share in the responsibility for preparing culturally and community responsive teachers to teach everyone's children' (p. 10-11). Such an approach moves away from narrow conceptions of status, 'quality' and literacy and numeracy results, and focuses on increasing actual quality of students' experiences, and embraces timely and substantive engagement with and in research to enhance neophyte teachers' capacities to enrich their students' learning experiences, and citizenship capacities more broadly. Such approaches take context seriously and are not simply dominated by neoliberal and economistic logics or various kinds of policy borrowing processes devoid of grounded understandings of local circumstances. 


\section{Notes}

1. This is a challenging process in the Australian case where different aspects of initial teacher education are the responsibility of individual states and the federal government. Various federal policies relate to the provision of national standards, for example, in initial teacher education, but registration of teachers according to these standards is undertaken at the state level. Even though there has been increased national attention to initial teacher education, we acknowledge that this is mediated differently in different national contexts.

2. Interestingly, research and development (R\&D) seems to be associated with an inclusive conception of research and development, beyond the business-oriented connotations of the term in Anglo (and some other) contexts.

3. See https://www.nokut.no/prosjekter-i-nokut/apt/.

4. This focus on agriculture is a reflection of the influence of the National Party in Australia, a traditionally rural-based political party, with which the dominant Liberal Party is in a coalition government to remain in power.

5. Approximately 13 million Euros.

6. Approximately 49 million Euros.

7. It is also important to note that as this article was being finalised (November 2018), the Australian Government released a Parliamentary Committee, focused on the 'Status of the teaching profession'. This is the latest in a long line of similar inquiries into the nature of teachers' work, including issues of retention, career structures and burn-out amongst earlycareer teachers.

8. In response to criticism in the professional field, however, as of 11 June 2018, the legal obligation for teachers to enrol in the register was postponed. Only when it is clear what is needed to embed the register as a register 'of, for, and by the teacher' will the next steps be taken. (Dutch Government, 2017b, 2018b).

9. VMBO - Preparatory Secondary Vocational Education; HAVO - Senior General Secondary Education; MBO - Senior Secondary Vocational Education and Training (VET).

10. By contrast, Australian pre-service teachers must pass equivalent tests by the conclusion of their Education degrees/certification.

\section{Disclosure statement}

No potential conflict of interest was reported by the authors.

\section{Funding}

This work was supported by the Australian Research Council under Grant No. FT140100018

\section{Notes on contributors}

Dr lan Hardy is Associate Professor in Education at the School of Education, The University of Queensland, Australia. Dr Hardy researches and teaches the politics of educational policy and practice, with a considerable focus upon the nature of teachers' work and learning. He is author of The politics of teacher professional development: Policy, research and practice (Routledge; 2012) and his current work focuses on the nature of accountability practices in schooling systems, and the role of data in this work.

Rachel Jakhelln is a Professor in Education at the Department of Education at UiT the Arctic University of Norway. Professor Jakhelln's research is in the area of teacher education and the transition from study to work in school. Her teaching is in teacher education for primary and lower 
secondary school with a focus on school development, teachers' professional learning and knowledge about youth in society.

Ben Smit is a researcher at ICLON Graduate School of Teaching, Leiden University, The Netherlands. He researches, teaches, and advises in the field of teacher education, teacher research, and professional learning. In the last 15 years, his research has focused on action research and practitioner research in educational settings, specifically in teacher education. As well as methodological issues related to this type of research, student participation and the changing position of participants in educational research have become important foci of his research.

\section{ORCID}

lan Hardy (D) http://orcid.org/0000-0002-8124-8766

Rachel Jakhelln (iD) http://orcid.org/0000-0002-9313-2082

Ben Smit (iD) http://orcid.org/0000-0002-6144-6490

\section{Data availability statement}

The data described in this article are openly available in the Open Science Framework at DOI:10.17605/OSF.IO/TPA6U.

\section{References}

Akiba, M. (2017). Editor's introduction: Understanding cross-national differences in globalized teacher reforms. Educational Researcher, 46(4), 153-168.

Amrein-Beardsley, A., Lawton, K., \& Ronan, K. (2017). An elusive policy imperative: Data and methodological challenges when using growth in student achievement to evaluate teacher education programs' 'value-added'. Teaching Education, 28(3), 296-316.

Australian Government. (2015). Fact sheet: Australian government response - action now: Classroom ready teachers report. Canberra: Author.

Australian Government. (2016). Students first. Retrieved from https://www.studentsfirst.gov.au

Australian Government. (2018). Teacher quality. Retrieved from https://www.studentsfirst.gov.au/ teacher-quality

Biesta, G. (2010). Why 'what works' still won't work: From evidence-based education to value-based education. Studies in Philosophy and Education, 29(5), 491-503.

Brenner, N., Peck, J., \& Theodore, N. (2010). Variegated neoliberalization: Geographies, modalities, pathways. Global Networks: A Journal of Transnational Affairs, 10(2), 182-222.

Cochran-Smith, M. (2016). Foreword. In G. Beauchamp (Ed.), Teacher education in times of change (pp. X-xvi). Bristol, UK: Policy Press.

Cochran-Smith, M., Cummings Carney, M., Stringer Keefe, E., Burton, S., Chang, W.-C., Fernández, M. B., ... Baker, M. (2018). Reclaiming accountability in teacher education. New York: Teachers College Press.

Cochran-Smith, M., \& Fries, K. (2008). Research on teacher education: Changing times, changing paradigms. In M. Cochran-Smith, S. Feiman-Nemser, J. McIntyre, \& K. Demers (Eds.), Enduring questions in changing contexts: The third handbook of research on teacher education (pp. 1050-1093). London: Taylor \& Francis.

Connell, R. (2013). The neoliberal cascade and education: An essay on the market agenda and its consequences. Critical Studies in Education, 54(2), 99-112.

Darling-Hammond, L. (2010). The flat world and education: How America's commitment to equity will determine our future. New York: Teachers College Press.

Darling-Hammond, L. (2017). Teacher education around the world: What can we learn from international practice? European Journal of Teacher Education, 40(3), 291-309. 
Darling-Hammond, L., Burns, D., Campbell, C., Lin Goodwin, A., Hammerness, K., Low, E.-L., ... Zeichner, K. (2017). Empowered educators: How high-performing systems shape teaching quality around the world. San Francisco: Jossey-Bass.

Dutch Government. (2013). Lerarenagenda 2013-2020. de leraar maakt het verschil [The teacher agenda: The teacher makes the difference]. Den Haag, The Netherlands: Rijksoverheid.

Dutch Government. (2016). Rekenonderwijs blijven verbeteren [Keep improving math education]. Retrieved from https://www.rijksoverheid.nl/onderwerpen/taal-en-rekenen/rekenonderwijsblijven-verbeteren

Dutch Government. (2017a). Lerarenregister aangenomen door de Eerste Kamer [Teacher Register passed first chamber]. Retrieved from https://www.rijksoverheid.nl/onderwerpen/werken-in-hetonderwijs/nieuws/2017/02/21/lerarenregister-aangenomen-door-eerste-kamer

Dutch Government. (2017b). Wet beroep leraar en lerarenregister [Act teacher profession and teacher register]. Retrieved from https://www.rijksoverheid.nl/onderwerpen/werken-in-hetonderwijs/wet-beroep-leraar-en-lerarenregister

Dutch Government. (2018a). Homepage Ministerie van Onderwijs, Cultuur en Wetenschap. Retrieved from https://www.rijksoverheid.nl/ministeries/ministerie-van-onderwijs-cultuur-en-wetenschap

Dutch Government. (2018b). Ingrijpende koerswijziging nodig voor verdere versterking positie leraar. [Drastic change of course needed for further strengthening teacher position]. Retrieved from https:// www.rijksoverheid.nl/onderwerpen/werken-in-het-onderwijs/nieuws/2018/06/11/ingrijpendekoerswijziging-nodig-voor-verdere-versterking-positie-leraar

Dutch Government. (2018c). Verbeteren positie en kwaliteit leraren [Improving teacher position and quality]. Retrieved from https://www.rijksoverheid.nl/onderwerpen/werken-in-het-onderwijs /kwaliteit-leraren-verbeteren

Friedrich, D., Walter, M., \& Colmenares, E. (2015). Making all children count: Teach for all and the universalizing appeal of data. Education Policy Analysis Archives, 23(48), 1-18.

Furlong, J., Cochran-Smith, M., \& Brennan, M. (2009). Introduction. In J. Furlong, M. Cochran-Smith, \& M. Brennan (Eds.), Policy and politics in teacher education: International perspectives (pp. 1-8). Abingdon, UK: Routledge.

Gilroy, P. (2014). Policy interventions in teacher education: Sharing the english experience. Journal of Education for Teaching, 40(5), 622-632.

Gray, D., \& Weir, D. (2014). Retaining public and political trust: Teacher education in Scotland. Journal of Education for Teaching, 40(5), 569-587.

Green, B., Reid, J., \& Brennan, M. (2017). Challenging policy, rethinking practice: Struggling for the soul of teacher education. In T. Trippestad, A. Swennen, \& T. Werler (Eds.), The struggle for teacher education: International perspectives on governance reforms (pp. 39-55). London: Bloomsbury.

Hansén, S.-E., Forsman, L., Aspfors, J., \& Bendtsen, M. (2012). Visions for teacher education experiences from Finland. Acta Didactica Norge, 6(1), 1-17.

Hansén, S.-E., Sjöberg, J., \& Eilertsen, T. V. (2014). Finske reformideer i norsk lærerutdanningsdiskurs [Finnish reform ideas in Norwegian teacher education discours]. In K. A. Røvik, T. V. Eilertsen, \& E. M. Furu (Eds.), Reformideer i norsk skole. Spredning, oversettelse og implementering [Reform ideas in the Norwegian School. Dissemination, translation and implementation] (pp. 167-195). Oslo: Cappelen Damm Akademisk.

Harvey, D. (2005). A brief history of neoliberalism. Oxford: Oxford University Press.

Hökkä, P., \& Eteläpelto, A. (2014). Seeking new perspectives on the development of teacher education: A study of the finnish context. Journal of Teacher Education, 65(1), 39-52.

Howe, E. (2014). A narrative of teacher education in Canada: Multiculturalism, technology, bridging theory and practice. Journal of Education for Teaching, 40(5), 588-599.

Kickert, W. (1995). Steering at a distance: A new paradigm of public governance in dutch higher education. Governance, 8, 135-157.

Mayer, D. (2014). Forty years of teacher education in Australia: 1974-2014. Journal of Education for Teaching, 40(5), 461-473.

Menter, I. (2016). Introduction. In G. Beauchamp (Ed.), (The teacher education group) Teacher education in times of change (pp. 3-18). Bristol: Policy Press. 
Miles, M., \& Huberman, A. (1994). Qualitative data analysis (2nd ed.). Thousand Oaks, CA: Sage.

Munthe, E., \& Rogne, M. (2015). Research based teacher education. Teaching and Teacher Education, $46,17-24$.

Murray, J. (2008). Towards the re-articulation of the work of teacher educators in higher education institutions in England. European Journal of Teacher Education, 31(1), 17-34.

Norwegian Government. (2016). Promotion of the status and quality of teachers. Retrieved from https://www.regjeringen.no/en/topics/education/innsikt/larerloftet/id2008159/

Norwegian Government. (2017). Teacher education 2025: National strategy for quality and cooperation in teacher education. Retrieved from https://www.regjeringen.no/contentassets/d0c1da83b ce94e2da21d5f631 bbae817/kd_teacher-education-2025_uu.pdf

OnderwijsBewijs. (2014). Didactief (Vol. 44, pp. 8).Amsterdam: Didaktief.

Page, T. (2015). Common pressures, same results? Recent reforms in professional standards and competences in teacher education for secondary teachers in England, France and Germany. Journal of Education for Teaching, 41(2), 180-202.

Peck, J., \& Theodore, N. (2015). Fast policy: Experimental statecraft at the thresholds of neoliberalism. Minneapolis: University of Minnesota Press.

Rowe, E., Lubienski, C., Skourdoumbis, A., Gerrard, J., \& Hursh, D. (2019). Templates, typologies and typifications. Discourse: Studies in the Cultural Politics of Education, 40(2), 150-161.

Savage, G. C. (2019). What is policy assemblage? Territory, Politics, Governance, 1-17. doi:10.1080/ 21622671.2018.1559760

Schatzki, T. (2002). The site of the social: A philosophical account of the constitution of social life and change. University Park, PA: The Pennsylvania State University Press.

Schriewer, J. (2000). World system and interrelationship networks. In T. Popkewitz (Ed.), Educational knowledge: Changing relationships between the state, civil society and the educational community (pp. 305-343). Albany: State University of New York Press.

Sellar, S., \& Lingard, B. (2013). Looking east: Shanghai, PISA 2009 and the reconstitution of reference societies in the global education policy field. Comparative Education, 49(4), 464-485.

Slavin, R. (2002). Evidence-based education policies: Transforming educational practice and research. Educational Researcher, 31(7), 15-21.

Solbrekke, T., \& Sugrue, C. (2014). Professional accreditation of initial teacher education programmes: Teacher educators' strategies - between 'accountability and 'professional responsibility?'. Teaching and Teacher Education, 37, 11-20.

Steiner-Khamsi, G. (2000). Transferring education, displacing reforms. In J. Schriewer (Ed.), Discourse formation in comparative education (pp. 155-187). New York: Peter Lang.

Straubhaar, R., \& Friedrich, D. (2015). Theorizing and documenting the spread of teach for all and its impact on global education reform. Education Policy Analysis Archives, 23(44), 1-7.

Takayama, K. (2010). politics of externalization in reflexive times: Reinventing Japanese education reform discourses through "Finnish PISA Success". Comparative Education Review, 54(1), 51-75.

Teacher Education Ministerial Advisory Group (TEMAG). (2014). Action now: Classroom ready teachers. Canberra: Department of Education.

Tirri, K. (2014). The last 40 years in Finnish teacher education. Journal of Education for Teaching, 40(5), 600-609.

Toom, A., \& Husu, J. (2012). Finnish teachers as 'makers of the many': Balancing between broad pedagogical freedom and responsibility. In H. Niemi, A. Toom, \& A. Kallioniemi (Eds.), The miracle of education: The principles and practice of teaching and learning in Finnish schools (pp. 39-54). Rotterdam: Sense Publishers.

Trippestad, T., Swennen, A., \& Werler, T. (2017). The struggle for teacher education. In T. Trippestad, A. Swennen, \& T. Werler (Eds.), The struggle for teacher education: International perspectives on governance reforms (pp. 1-16). London: Bloomsbury.

Werler, T. (2017). Learning sciences: Reconfiguring authority in teacher education. In T. Trippestad, A. Swennen, \& T. Werler (Eds.), The struggle for teacher education: International perspectives on governance reforms (pp. 131-145). London: Bloomsbury. 
Zeichner, K. (2014). The struggle for the soul of teaching and teacher education in the USA. Journal of Education for Teaching, 40(5), 551-568.

Zeichner, K. (2018). The struggle for the soul of teacher education. New York: Routledge.

Zwart, R., Smit, B. H. J., \& Admiraal, W. (2015). Docentonderzoek nader bekeken: Een reviewstudie naar de aard en betekenis van onderzoek door docenten [A closer look at teacher research: A review study into the nature and meaning of teachers' practitioner research]. Pedagogische Studiën, 92(2), 131-148. 